\title{
Analisis Kemampuan Daya Dukung Lahan Menggunakan Carring Capacity Ratio (CCR) di Kabupaten Dompu
}

\author{
Febrita Susanti dan Agus Kurniwan \\ Program Studi Perencanaan Wilayah dan Kota, Universitas Muhammadiyah Mataram \\ febrita s@yahoo.com
}

INFO ARTIKEL

\section{RiwayatArtikel:}

Diterima: 13-12-2016

Disetujui: 03-02-2017

\section{Kata Kunci:}

Daya dukung

lahan

Pertanian

CCR

\begin{abstract}
ABSTRAK
Abstrak:Penelitian daya dukung lahan ini diilakukan bertujuan untuk mengetahui kemampuan daya dukung pertanian terhadap lingkungannya. Jenis penelitina ini adalah penelitian deskriptif kuntitatif dengan menggunakan analisis carrying capacity ratio. Hasil penelitian ini menunjukan bahwa sector pertanian mampu mendukung pertumbuhan daerah serta memenuhi kebutuhan pokok penduduk di Kabupaten Dompu. Empat kecamatan mempunyai nilai CCR mendekati anggka = 1, yaitu Kecamatan Woja, Kecamatan Kilo, Kecamaan Kempo dan Kecamatan Pekat yang artinnya bahwa lahan pertanian yang ada di setiap kecamatan tersebut memiliki daya dukung yang cukup tinggi terhadap aktifitas pembangunan seperti Kecamaan dengan nilai rasio daya dukung 1,7 yang berarti bahwa di setiap rumah tangga biasa memiliki lahan seluas 1,7 ha, artinya lebih besar 0,83 ha dari luas lahan rata-rata yang dimiliki oleh setiap rumah tangga petani. Kecamatan manggelewa memiliki rasio daya dukung sama dengan 1 (=1), yang berarti kecamatan tersebut masih memiliki keseimbangan antara kemampuan lahan dari jumlah penduduknya.
\end{abstract}

\begin{abstract}
The research on carrying capacity of this land was carried out aimed to determine the ability of carrying capacity of agriculture to its environment. This type of research is quantitative descriptive research using carrying capacity ratio analysis. The results of this study indicate that the agricultural sector is able to support regional growth and meet the basic needs of the population in Dompu District. Four sub-districts have CCR values approaching members $=1$, namely WojaSubdistrict, Kilo Subdistrict, KempamaanSubdistrict and PekatSubdistrict which means that agricultural land in each of these sub-districts has a sufficiently high carrying capacity for development activities such as Equity with dkung power ratio 1, 7 which means that every ordinary household has a land area of 1.7 ha, meaning that it is greater than 0.83 ha of the average land area owned by each farmer household. Manggelewa sub-district has a carrying capacity ratio equal to 1 $(=1)$, which means that the sub-district still has a balance between the ability of the land and the population.
\end{abstract}

\section{A. LATAR BELAKANG}

Perkembangan sector pertannian dalam upaya peningkatan produksi pertanian dihadapkan pada tantangan secara biosfisk, yaitu (Haryono, 2011 - 1):

a. Kerusakan dan degrasi sumber daya lahan dan air dengan isusoil sickness fatique penurunan kesuburan/produktifitas dan pencemaran

b. Peningkatan variabilitas dan terjadinya perubahan iklim

c. Penciutan dan alih fungsi (konservasi) lahan pertanian subur

d. Fragmentasi lahan pertaian

Dalam memanimalisir tantangan tersebut maka perlu adanya suatu strategi untuk meningktankan produksi sektor pertanian. Sektor pertanian di
Kabupaten Dompu merupakan sumber pendapatan daerah berasa dari sektor ini.pembangunan sektor pertanian di Kabupaten Dompu di arahkan mamantapkan program swasembada pangan.

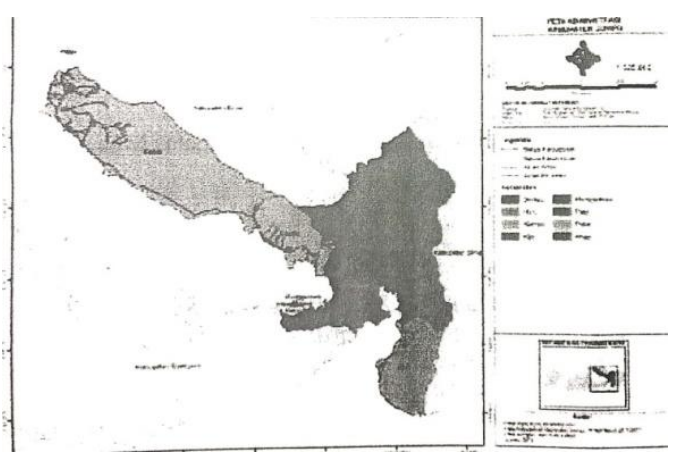

Gambar 1. Peta Administrasi Kabupaten Dompu 
Kabupaten Dompu berbatas dengan Laut Flores dan kabupaten bima di sebelah selatan utara, sebelh selatan berbatas dengan lau indonesia, sebelah barat berbatas dengan Kabupaten Sumbawa dan Sebelah Timur Berbatas dengan Kabupaten Bima. Penduduk kabupaten Dompu pada tahun 2016 berjumlah 238.385 jiwa dengan kepadatan penduduk 102,55 jiwa/km2. Kabupaten Dompu mempunyai 8 kecamatan yaitu Kecamatan Hu,u, Kecamatan Kempo, Kecamatan Kilo, Kecamatan Manggelewa, Kecamatan Pekat, Kecamatan Woja, Kecamatan Pojo dan Kecamatan Dompu.

Kabupaten Doumpu memiliki luas wilayah 232.455 ha dengan penutupan lahan dominan hutan lindung dan hutan produksi seluas 73\% (1692.62 ha) . penutupan lahan berupa tanah sawah di Kabupaten Dompu mencapai $(9,93 \%)$ dimana luasan tanah sawah terluas berada di Kecamatan Pajo seluas 5.14 ha. Untuk lebih rincinyaproporsi luasan lahan sawah di ada masing masing Kecmatan dapat dilihat pada tabel berikut.

Tabel 1.

Luas wilayah sawah perkecamatan di Kabupaten Dompu

\begin{tabular}{cll}
\hline No & \multicolumn{1}{c}{ Kecamatan } & Luas (Ha) \\
\hline 1 & Hu,u & 3.060 \\
2 & Kempo & 1.059 \\
3 & Kilo & 78 \\
4 & Manggelewa & 3.030 \\
5 & Pekat & 2.382 \\
6 & Woja & 4.686 \\
7 & Pajo & 5.146 \\
8 & Dompu & 3.636 \\
& Jumlah & 23.077
\end{tabular}

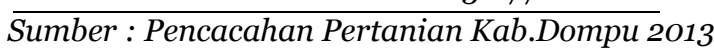

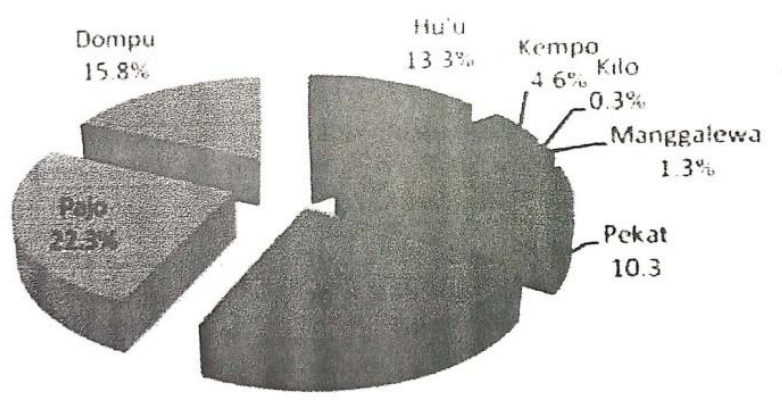

Gambar 2. Presentase Luas Sawah Perkecamatan Di Kabupaten Dompu

Sumber : Kab.Dompu Dalam Angka 2016

Sehingga berdasarkan luasan lahan pertanian yang tersedia saat ini dengan jumlah penduduk 238.385 jiwa pada tahun 2016 maka diperlukan upaya untuk menentukan kemampuan daya dukung lahan sawah dalam memenui kebutuhan pokok penduduk terkait dengan potensi unggulan pertanian di Kabupaten Dompu.
Penelitian ini bertujuan untuk mengetahui dukungan dari suatu area atau luasan lahan sangat penting dalam perencanaan pembangunan guna memperkirakan berbagai kemungkinan yang dapat terjadi atau memperkirakan tingkat kebutuhan penduduk yang disesuaikan dengan kondisi lahan yang ada, maka penelitian ini di buat untuk mengetahui gambaran nilai rasio daya dukung lahan yang dimiliki setiap Kecamatan di KabupatenDompu.

\section{B. METODE PENELITIAN}

Penelitian ini menggukan metode deskriptif kualitatif. Data digunakan merupakan data sekunder dari Badan Pusat Statistik, Dinas Pertanian dan Bappeda Kabupaten Dompu.

Dalam penelitian ini penentuan kemampuan daya dukung, analisis yang digunakan adalah analisis CCR (carring capacity ratio),

$$
C C R=\underline{\mathrm{Axr}}
$$

$\mathrm{HXhxF}$

Keteranagan :

CCR : Kemampuan daya dukung

A : Jumlah total area yang digunakan untuk kegiatan pertanian

$\mathrm{r} \quad$ : Frekuensi panen per hektar pertahun

$\mathrm{H} \quad$ : Jumlah KK (rumah tangga)

$\mathrm{h} \quad$ : Presentase jumlah penduduk yang tinggal

F : Ukuran lahan pertanian rata-rata yan dimilikki petani

CCR $>1$ berdasarkan kuantitas lahannya, suatu wilayah masih memiliki kemampuan untuk mendukung kebutuhan pokok penduduk dan mampu menerima tambahan penduduk, pembangunan masih di mungkinkan bersifat ekpansif dan ekspoloratif lahan.

CCR $<1$ Sebaliknya berdasarkan jumlah lahan yang ada, wilayah tersebut sudah tidak mungkin dilakukan pembangunan yang bersifat ekpansif dan ekspoloratif lahan CCR = 1

\section{HASIL DAN PEMBAHASAN}

Analisis kemampuan daya dukung lahan menggunakan beberapa variabel yang dapat dilihat pada tabel dibawah ini:

Tabel 2.

Variabel Penelitian

\begin{tabular}{lccccc}
\hline \multirow{2}{*}{ Kecamatan } & \multicolumn{5}{c}{ Variabel } \\
\cline { 2 - 6 } & (Axr) & (Ho) & Jml & (h) & (F) \\
Jiwa & KK & \% & Ha/KK \\
\hline Hu,u & 5.925 & 4.768 & 2391 & 50 & 1 \\
Kempo & 686.097 & 3.298 & 2221 & 67 & 2 \\
Kilo & 10.390 & 12.663 & 3238 & 26 & 1,12 \\
Manggelewa & 7.876 & 13.381 & 5403 & 40 & 0,87 \\
Pekat & 125 & 3.049 & 1184 & 39 & 0,07 \\
Woja & 1.441 & 4.745 & 1600 & 34 & 0,66 \\
Pajo & 3.180 & 7.137 & 4471 & 63 & 0,68 \\
Dompu & 4.121 & 8.866 & 4352 & 49 & 0,55 \\
\hline Sumber $:$ Hasil Olahan Data & & & &
\end{tabular}


Dari table diatas dapat diketahuii nilai setiap variabel, seperti variabel (Axr) merupakan variable luas lahan pertanian sawah dan frekuensi panen per tahun, variabel $(\mathrm{H})$ merupakan jumlah keseluruhan rumah tangga (KK) yang ada di setiap kecamatan di Kabupaten Dompu, variabel(h) merupak persen jumlah KK petani per kecamatan serta variabel (f) penguasaan lahan pertanian per KK dalam Ha.

Berdasarkan analisis carriying capacity ratio (CCR) maka dapat hasil sebagi berikut:

Tabel 3.

Hasil Analisi CCR per Kecamatam

\begin{tabular}{lcc}
\hline Kecamatan & CCR & Keterangan \\
\hline Hu,u & 2,5 & $>1$ \\
Kempo & 154,5 & $>1$ \\
Kilo & 2,9 & $>1$ \\
Manggelewa & 1,7 & $>1$ \\
Pekat & 1,5 & $>1$ \\
Woja & 1,4 & $>1$ \\
Pajo & 1,0 & $=1$ \\
Dompu & 1,7 & $>1$ \\
\hline Sumber :
\end{tabular}

Sumber : Hasil Analisis

Berdasarkan hasil penelitian yang di gambarkan pada tabel diatas dapat di ketahui nahwa sebagian besar lahan kecamatan di Kabupaten Dompu masih mampu mendukung kebutuhan pokok penduduknya dan masih menerima tambhaan penduduk. Hal ini di sebabkan karena masih rendahnya tingkat kepadatan penduduk dan masih besarnya penguasaan laha pertanian oleh sebagian besar rumah tangga di Kabupaten Dompu.

Empat kecamatan mempunyai nilai CCR mendekati angka $=1$, yaitu Kecamatan Woja, Kecamatan Kilo, KecamatanPekat, KecamatanKempo yang artinya bahwa lahan pertanian sawah yang ada di setiapkecamatantersebutmasih memiliki daya dukung yang tinggi terhadap aktifitas pembangunan seperti Kecamatan Woja dengan nilai rasio daya dukung 1,7 yang berarti bahwa disetiap rumah tangga biasa memiliki lahan seluas 1,7 ha, artinya lebih besar daro 0,83 ha dari luas lahan rata-rata yang dimiliki oleh setiap rumah tangga petani.

Kecamatan Manggelewa dari tabel diatas menunjukan rasio daya dukungnya bernillai sama dengan $1(=1)$, yang berarti kecamatan tersebut masih memiliki keseimbangan antara kemampuan lahan dengan jumlah penduduknya. Kebutuhan pokok masih juga dapat diatasi, namun perlu adanya kewaspadaan oleh pemerintah daerah karena proses pembangunan yang cepat dan pertumbuhan penduduk yang kurang terkendali dapat dengn cepat menyebabkan menurunya kemampuan daya dukung lahan di daerah tersebut.

Menurut riyadi (2002), besar penduduk dalam suatu ruang (wiayah) akan sangat menentukan kemampuan suau wilayah tersebut untuk mendukung penduduknya, sehingga memperoleh standar hidup yang layak. Kabupaten Dompu dengan memiliki kemampuan daya dukung yang sebagian besar kecamaanya diharapkan mampu espansid dan melakukan eksploratif lahan.

\section{SIMPULAN DAN SARAN}

Hasil penelittian daya dukung lahan pertanian sawah dapat memberikan gamabaran bahwa tujuan kecamatan di Kabupaten Dompu memiliki rasio daya dukung lebih dari 1 yang bearti masih ampu mendukung kebutuhan pokok penduduk dan mampu menerima tambahan penduduk, pembangunanmasih mungkin bersifat ekspansi dan ekploratif lahan. Satu kecamatan yang memiliki rasio daya dukung sm dengan 1 yang berarti masih memilki keseimbangan antara kemampuan lahan dan jumlah penduduk.

Berdasrkan hasil penelitian ini, maka penulis merekomendasikan berupa saran -saran sebagi berikut:

1. Kepada pemerintah daerah agar bisa mengantisipasi segala kemungkinan yang terjadi akibat dari menurunya daya dukung lahan, misalnya dengan melakukan pnekanan penduduk, memperluas $\mathrm{p}$ ertanian sawah atau juga dengan menaikan produktifitas pertanian padi sawahh dan ladang.

2. Penelitian ini belum komprehensip,karena rasio daya dukung lahanya hanya terbatas pada lahan sawah maka unukk kebutuhan penelitian berikutnya bisa meneliti rasio daya dukung lahan pada sekuruh komoditas pertanian.

\section{DAFTAR RUJUKAN}

[1] Kabupaten dalam angka 2016, BPS, KabupatenDompu

[2] Kecamatan Hu'u dalam angka 2016, BPS, Kabupaten Dompu

[3] Kecamatan Kilo dalam angka 2016, BPS, Kabupaten Dompu

[4] Kecamatan Woja dalam angka 2016, BPS, Kabupaten Dompu

[5] Kecamatan Pekat dalam angka 2016, BPS, Kabupaten Dompu

[6] Kecamatan Dompu dalam angka 2016, BPS, Kabupaten Dompu

[7] Kecamatan Kempo dalam angka 2016, BPS, Kabupaten Dompu

[8] Kecamatan Manggelewa dalam angka 2016, BPS, Kabupaten Dompu

[9] Kecamatan pajo dalam angka 2016, BPS, Kabupaten Dompu

[10]Pencacahan pertanian Kabupaten Dompu, 2016, BPS Kabupaten Dompu

[11] Muta'alilutfi, 2012, Daya Dukung Lingkungan untuk perencanaan Pembangunan Wilayah,Yogyakarta, BPFG Universitas Gadjah Mada.

[12] Valeria Anggela,dkk, KemampuanDayaDukung Serta Penetuan Sub Sector Andalan Dan Unggulan Sector PertanianKabupatenLandak, Kalimantan Barat, 2007, salatiga: AGRIC Vol 19, No.1, ukSW 